\title{
NIGERIA'S ENGAGEMENT WITH THE HUMAN RIGHTS COUNCIL'S UNIVERSAL PERIODIC REVIEW: POTENTIAL FOR ACCULTURATION OR RISK OF REGRESSION?
}

By

\section{DAMIAN ETONE*}

\section{INTRODUCTION}

After gaining independence from British colonial rule in 1960, considerable efforts were made to promote and protect human rights in Nigeria. The post-independence constitutions of Nigeria guaranteed human rights and instituted mechanisms for their enforcement. ${ }^{1}$ The Nigerian National Human Rights Commission was established in 1995. 2 However, from 1966 to 1999 , eight military coups destabilised Nigeria and negatively impacted on human rights protection in the country. ${ }^{3}$ There has since been a return to civilian rule with some relative gains in the promotion and protection of human rights. Nevertheless, extrajudicial killings, impunity by security forces and prolonged pre-trial detention have remained a human rights challenge. ${ }^{4}$ These have become more challenging by the terrorism activities of Boko Haram, and the antiterrorism efforts of the government in striking a balance with respect for human rights. Many of these human rights issues have featured prominently in the engagement of Nigeria with the Universal Periodic Review (UPR) mechanism of the Human Rights Council.

The UPR is a unique mechanism of the Human Rights Council (HRC) which relies entirely on cooperation and dialogue to implement human rights. Unlike other UN human rights mechanisms, states are the principal actors and reviewers in the UPR mechanism. The review takes place every 4.5 years in three main stages which include the preparation of state reports, review of the state in Geneva and the follow-up process. The four major principles underlying the review include objectivity, universality, cooperation and complementarity ${ }^{5}$ and with the

\footnotetext{
*LLB (Hons), LLM (Distinction), PhD; Lecturer, School of Law, Staffordshire University, UK.

${ }^{1}$ See Section 32, 1963; 42, 1979; and 46, 1999 Constitutions of Nigeria.

${ }^{2}$ It was established by the National Human Rights Commission (Amendment) Act, 1995. In 2010, it was amended by the National Human Rights Commission Act, 2010, to enable it re-attained A Status.

${ }^{3}$ Jacob Abiodun Dada, Human Rights Protection in Nigeria: The Past, the Present and Goals for Role Actors for the Future' (2013) 14 Journal of Law Policy and Globalisation, 5-6; D O Aihe, 'Fundamental Human Rights and the Military Regime in Nigeria: What Did the Courts Say?' (1971) 15 (2) Journal of African Law 213-244.

${ }^{4}$ See Nigeria National Human Rights Commission, The State of human rights in Nigeria: 2009-2010 (National Human Rights Commission 2010) 3-40.

${ }^{5}$ Human Rights Council, Institution Building of the United Nations Human Rights Council, HRC Res. 5/1, UN HRC OR, 5th sess, Annex [IB], UN Doc A/HRC/RES/5/1 paras [3] and [4].
} 
principal objective of improving human rights situation on the ground. ${ }^{6}$ The legal basis of the review include the UN Charter, the Universal Declaration of Human Rights, binding human rights treaties, voluntary pledges and commitments made by states and applicable international humanitarian law. ${ }^{7}$ The review equally welcomes the participation of NGOs, albeit limited, during the plenary session of the HRC when a state report is being adopted. ${ }^{8}$ The first cycle of the review (hereinafter UPR I) spanned from 2008-2011 and the second cycle (hereinafter UPR II) was undertaken from 2012-2016.

\section{I.1. Can the UPR be an Effective Human Rights Monitoring Mechanism?}

Whether the UPR is an effective mechanism for monitoring the human rights compliance of states has been a source of contention among many scholars. Some authors argue that human rights mechanisms that rely on the cooperation of states are weak and cannot meaningfully advance human rights. ${ }^{9}$ Olivier de Frouville argued that the UPR 'has failed to live up to expectations' because it overshadows the hard work of the treaty bodies, is wholly dependent upon the goodwill of states and cannot, as a political entity, make a legal assessment or interpretation of the human rights obligations of states. ${ }^{10}$ He advocates for a more confrontational mechanism - the establishment of a World Commission of Human Rights. ${ }^{11}$ This echoes the sentiments of some international relations and international law scholars who advocate for a more coercive compliance paradigm. They contend that compliance with human rights norms is largely a function of powerful states' (or institutions') willingness

\footnotetext{
6 ibid [4a].

7 ibid [1]; Nadia Bernaz has questioned some of the legal basis for the UPR see Nadia Bernaz, 'Reforming the UN Human Rights Procedure: A Legal perspective on the Establishment of the Universal Periodic review' in Kevin Boyle, New Institutions for Human Rights Protection (Oxford University Press, 2009) 79-82; There is also contention on the inclusion of humanitarian law as a basis for the review. See Lijiang Zhu, 'International Humanitarian Law in the Universal Periodic Review of the UN Human Rights Council' (2014) 5 Journal of International Humanitarian Legal Studies 186, 209-210.

${ }^{8}$ Human Rights Council, Institution Building of the United Nations Human Rights Council, (note 5 above) [31].

${ }^{9}$ Makau Mutua, 'Looking past the Human Rights Committee: An Argument for De-marginalising Enforcement (1994) 4 Buffalo Human Rights Review 211, 211-212; Keith, Linda Camp, 'The United Nations International Covenant on Civil and Political Rights: Does It Make a Difference in Human Rights Behavior?' (1999) 36 Journal of Peace Research 95-118; Hafner-Burton Emilie and Kiyoteru Tsutsui, 'Justice Lost! The Failure of International Human Rights Law to Matter Where Needed Most' (2007) 44 (4) Journal of Peace Research: 407-25.

${ }^{10}$ Olivier de Frouville, 'Building a Universal System for the Protection of Human Rights' in M.Cherif Bassouni and William A Schabas (eds), New Challenges for the UN Human Rights Machinery: What Future for the UN Treaty Body System and the Human Rights Council Procedures? (Intersentia, 2011) 250-55; For a similar argument see Nadia Bernaz, 'Reforming the UN Human Rights Protection Procedures: A Legal Perspective on the Establishment of the Universal Periodic Review' in Kevin Boyle (ed), New Institutions for Human Rights Protection (Oxford University Press, 2009) 79-91.

${ }^{11}$ Olivier also supports the establishment of a World Court of Human Rights see De Frouville (note 10 above) 264-265.
} 
to enforce them. ${ }^{12}$ An alternative argument is that human rights institutions can only create impact when created with the power to enforce the norms and punish state violation. ${ }^{13}$

Another strong critic of the UPR mechanism is Manfred Nowak. Nowak, former UN Special Rapporteur on Torture, argues that the UPR 'suffers from the disadvantage that states' performance in the field of human rights is assessed by other states rather than by independent experts. ${ }^{, 14}$ For Nowak, the UPR, by not permitting special rapporteurs and treaty body experts to participate in the review, undermines the work of the treaty bodies and special procedures. The general presumption which underlies the criticisms of de Frouville and Nowak is that monitoring human rights implementation is best tackled by human rights expert bodies rather than states. However, their analyses undermine the potential value of the UPR and do not provide empirical data on whether the UPR is effective or not in improving the human rights situation of states.

Exclusive reliance on "strong" enforcement mechanisms would undermine the potential of cooperative mechanisms. Avoiding human rights rhetoric or ritualism does not necessary require "strong" enforcement mechanism. About 25 years ago, Opsahl advocated for the necessity of a "softer approach" rather than the traditional notion of "right-breachresponsibility-process-sanction, leading to punishment of any violator or at least to redress for any victim." ${ }^{15}$ Kenneth Roth has argued that coercive mechanisms are not suitable to deal with violations of economic, social and cultural rights. ${ }^{16}$ There has also been evidence that questions the effectiveness of coercive mechanisms. Empirical analysis from 1981-2000 concluded that

\footnotetext{
${ }^{12}$ Stephen D Krasner, 'Sovereignty, Regimes, and Human Rights' in Volker Rittberger and Peter Mayer (eds), Regime Theory And International Relations (Clarendon Press, 1995) 165-67; A M Weisburd, 'Implications of International Relations Theory for the International Law of Human Rights' (1999) 38 Columbia Journal of Transnational Law 45, 101-11.

${ }^{13}$ Olivier de Frouville, 'Building a Universal System for the Protection of Human Rights' in M Cherif Bassouni and William A Schabas (eds), New Challenges for the UN Human Rights Machinery: What Future for the UN Treaty Body System and the Human Rights Council Procedures? (Intersentia 2011) 253-66; Henry J Steiner, 'Individual Claims in a World of Massive Violations: What Role for the Human Rights Committee?' in Phillip Alston and James Crawford (eds), The Future of United Nations Treaty Monitoring (Cambridge University Press, 2000) 15.

${ }^{14}$ Manfred Nowak, 'It's Time for a World Court of Human Rights' in M Cherif Bassiouni and William A Schabas (eds), New Challenges for the UN Human Rights Machinery (Intersentia, 2011), 23.

15 Torkel Opsahl, 'Instruments of Implementation of Human Rights' (1989) 10(1-2) Human Rights Law Journal 13, 31-32.

${ }^{16}$ Kenneth Roth is the executive director of Human Rights Watch. See Kenneth Roth, 'Defending Economic, Social and Cultural Rights: Practical Issues Faced by and International Human Rights Organization' (2004) 26 (1) Human Rights Quarterly 63.
} 
“economic sanctions deteriorate citizens' physical integrity rights"17 especially when directed towards dictatorial regimes. ${ }^{18}$ The UPR mechanism which relies on cooperation and gives the state some degree of control over the process can be sometimes at least as, if not more effective than coercive mechanisms.

Since 2012, Rhona Smith, Helen Quane and Takele Bulto have analysed the impact of the UPR in different regions. ${ }^{19}$ Smith's 2012 case study of Pacific Island states demonstrated that these states actively engaged with the interactive dialogue of their reviews during UPR I and were receptive to UPR recommendations. Smith, nevertheless, pointed to the fact that their engagement was limited by their inability to participate in the review of other states due to technical and financial constraints. ${ }^{20}$ With regards to states within the Association of Southeast Asian Nations (ASEAN), Quane argued in 2015 that the UPR mechanism has enhanced the relationship between ASEAN states and the global human rights mechanisms. ${ }^{21}$ According to Quane, the UPR impacts other mechanisms by making particular recommendations which have increased their engagement with the UN treaty bodies and special procedures. ${ }^{22}$ Quane's case study also highlighted the fact that disagreements on the death penalty and the rights of LGBT persons have limited the engagement of many states in the region. ${ }^{23}$ In Bulto's 2015 general analysis on Africa, he found that African states engage more with the UPR mechanism than with other human rights mechanisms because of the almost complete control they have over

\footnotetext{
${ }^{17}$ Dursun Peksen, 'Better or Worse? The Effect of Economic Sanctions on Human Rights' (2009) 46 (1) Journal of Peace Research, 59. Also relevant is Mohamed Bennouna, 'Les sanctions économiques des Nations Unies' (2002-I) 200 RCADI 9, 40-47.

${ }^{18}$ Cristiane Careniero and Dominique Elden, 'Economic Sanctions, Leadership survival and human rights' (2009) 30(3) University of Pennsylvania Journal of International Law, 969.

${ }^{19}$ See Helen Quane, 'The Significance of an Evolving Relationship: Asian States and the Global Human Rights Mechanisms' (2015) 15 Human Rights Law Review 283; Rhona Smith, 'A Review of African States in the First Cycle of the UN Human Rights Council's Universal Periodic Review' (2014) 14 African Human Rights Law Journal 346; Rhona Smith, 'The Pacific Island States: Themes Emerging from the United Nations Human Rights Council's Inaugural Universal Periodic Review' (2012) 13(1) Melbourne Journal of International Law, 569; Takele Soboka Bulto, 'Africa's Engagement with the Universal Periodic Review: Commitment or Capitulation' in Hilary Charlesworth and Emma Larking (eds), Human Rights and the Universal Periodic Review: Rituals and Ritualism (Cambridge University Press, 2015) 235-55.

${ }^{20}$ Smith, 'The Pacific Island States: Themes Emerging from the United Nations Human Rights Council's Inaugural Universal Periodic Review' above n 19, 594.

${ }^{21}$ ASEAN is an inter-governmental Asia regional arrangement comprising of 10 member states with the aim of promoting political, economic and social cooperation and regional stability. See Quane, 'The Significance of an Evolving Relationship: ASEAN States and the Global Human Rights Mechanisms’ above n 19, 289.

${ }^{22}$ Ibid.

${ }^{23}$ Ibid 289-95.
} 
the outcome of the UPR process. ${ }^{24}$ But he argues that their engagement lacks genuine commitment and is a manifestation of rights ritualism. ${ }^{25}$

This article provides the first comprehensive empirical analysis of Nigeria's engagement with the UPR mechanisms. It underscores the value of cooperation in monitoring human rights compliance by examining the effectiveness of Nigeria's engagement with the UPR mechanism. To evaluate the 'effectiveness' of Nigeria's engagement with the UPR, I employ an approach which evaluates 'effectiveness' in terms of the level of state commitment to the UPR process, participation during the review sessions and the aggregate percentage of implemented UPR recommendations. The benefit of this approach is that it provides important indicators to a state's level of engagement and enables a comprehensive assessment of that engagement by examining state engagement with the key stages of the UPR process. ${ }^{26}$ Also, this article considers the potential for acculturation and the impact of conflicts and terrorism on Nigeria's engagement with the UPR.

\section{NIGERIA AS A STATE UNDER REVIEW (SUR)}

Nigeria was reviewed by the UPR WG in February 2009 and October 2013 respectively. As a result of its membership of the HRC, the Nigerian government entered voluntary pledges and commitments which are included as part of the assessment basis for its review. Fifty-two states made recommendations to Nigeria during UPR I, 13 of which were African states. Out of a total of $32^{27}$ recommendations, 30 were accepted by the government of Nigeria. It accepted all the recommendations from African states. During UPR II, all states made a total of 219 recommendations to Nigeria of which it accepted $84 \%$. The high acceptance level evident in both UPR cycles indicates an active engagement with the recommendations. Some states like

\footnotetext{
${ }^{24}$ Bulto's analysis was a general evaluation of the participation of African states during UPR I. He did not engage in any specific case studies in his analysis. See Bulto, above n 19.

25 Ibid.

${ }^{26}$ For more details on this approach See Damian Etone, 'The Effectiveness of South Africa's Engagement with the Universal Periodic Review (UPR): Potential for Ritualism?' (2017) 33 (2) South African Journal on Human Rights 258, 260-61.

${ }^{27}$ These recommendations were gleaned from the WG reports. See UN Human Rights Council, Report of the Working Group on the Universal Periodic Review - Nigeria, 11 ${ }^{\text {th }}$ sess, Agenda Item 6, UN Doc A/HRC/11/26 (5 October 2009) ('HRC UPR I Report - Nigeria'), paras 18-24; several of these recommendations include more than one category of recommendation covering one or more issue(s). In the analysis in figure 4.5, these recommendations were separated to identify each in its own category and to easily identify implementation level. This totalled 115 recommendations. This total correspond with that stated by UPR info. See UPR Info < http://s.upr-info.org/1G1cXQV>.
} 
Botswana, China and South Sudan did not accept more than $50 \%$ of recommendations made to them during UPR I. South Sudan in particular did not accept more than $85 \%$ of the recommendations made to it during UPR I. ${ }^{28}$ Figures 1 and 2 below provide an analysis of Nigeria's engagement as a state under review. It depicts its review by African states compared to other groups of states. ${ }^{29}$ The category of recommendations and areas where Nigeria was most engaged are further examined in figures 3 and 4.

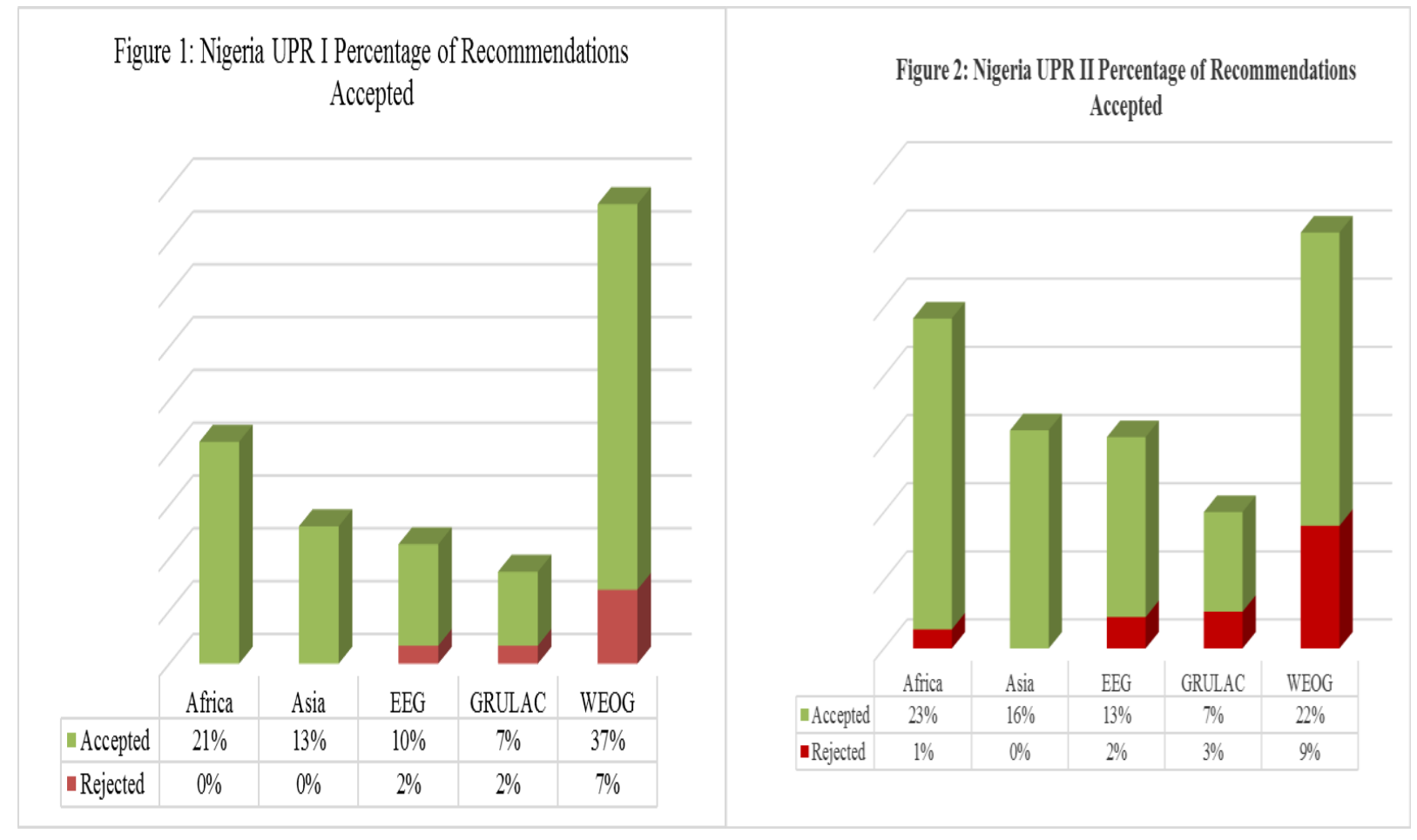

Figures 1 and 2 above indicate that Nigeria engaged with recommendations within and outside its regional group. However it maintained a stronger engagement within its African regional group. As seen in figure 1, Nigeria accepted all the recommendations from African states during UPR I. This constituted $21 \%$ of the total recommendations made to Nigeria during UPR I. Figure 2 shows that during UPR II it rejected only about $1 \%$ of recommendations from

${ }^{28}$ UN Human Rights Council, Report of the Working Group on the Universal Periodic Review - Sudan: Addendum-Views on conclusions and/or recommendations, voluntary commitments and replies presented by the State under review, $18^{\text {th }}$ sess, UN Doc A/HRC/18/16/Add.1 (16 September 2011) paras 1-35.

${ }^{29}$ There are 5 regional groups in the HRC: Group of African States; Group of Asian States; Group of Eastern European States (EEG); Group of Latin American and Caribbean States (GRULAC); and Group of Western European and other States (WEOG). See Human Rights Council, GA Res 60/251, UN GAOR, 60 ${ }^{\text {th }}$ sess, $72^{\text {nd }}$ plen mtg, Agenda Items 46 and 120, UN Doc A/Res/60/251 (3 ${ }^{\text {rd }}$ April 2006) ('Resolution 60/251') para 7. 
African states compared to about $9 \%$ of the recommendations rejected from WEOG. This finding would indicate that Nigeria is more receptive of intra-African recommendations and more likely to reject recommendations from Western states.

There was a remarkable increase in the total number of recommendations made to Nigeria across both cycles of the review, from 32 during UPR I to 219 during UPR II. The increase in the number of recommendations made to Nigeria may reflect the general increase in the number of recommendations which was evident during UPR II. ${ }^{30}$ However there may be other particular factors which may explain the rise in the number of recommendations to Nigeria. These are the escalation of the conflict between the government and Boko Haram after UPR I, ${ }^{31}$ the enactment of the Same Sex Marriage Prohibition Act in 2013 and the resumption of the death penalty in Nigeria. ${ }^{32} 38$ recommendations during UPR II were dedicated to addressing these three issues. The last two issues constituted the total 35 recommendations which were rejected by Nigeria during UPR II and the two rejected during UPR I. No recommendation on sexual orientation and gender identity was made by an African state (with the exception of Madagascar) and none of the recommendations made by non-African states on this issue were accepted by the Nigerian delegation. These recommendations were found by many African states to be "hyper-sensitive in political, social and/or cultural terms" 33 and "contravened deeply held beliefs or policy positions of governments." 34 Three African countries made recommendations related to the abolition of the death penalty. ${ }^{35}$ While Nigeria did not accept recommendations which related to the abolition of the death penalty, it surprisingly made a similar recommendation to Argentina. ${ }^{36}$

\footnotetext{
${ }^{30}$ Edward R McMahon, Kojo Busia and Marta Ascherio, 'Comparing Peer Reviews: The Universal Periodic Review of the UN Human Rights Council and the African Peer Review Mechanism' (2013) 12 African and Asian Studies 266, 280-82.

${ }^{31}$ Two bombings in the capital, Abuja in 2011 resulted in this escalation of violence. See Simeon H O Alozieuwa, 'Contending Theories on Nigeria's Security Challenge in the Era of Boko Haram Insurgency' (2012) 7(1) Peace and Conflict Review 1.

${ }^{32}$ About 600 people in early 2015 were on death row see Roger Hood and Carolyn Hoyle, The Death Penalty: A Worldwide Perspective (Oxford University Press, 2015) 274.

${ }^{33}$ Edward McMahon, 'The Universal Periodic review: A Work in Progress, An Evaluation of the First Cycle of the New UPR Mechanism of the United Nations Human Rights Council' (2012) Friedrich Ebert Stiftung 1, 18.

${ }^{34}$ Ibid.

35 The recommendations were made by Togo, Benin and Rwanda respectively.

${ }^{36}$ UN Human Rights Council, 'Report of the Working Group on the Universal Periodic Review - Argentina', $8^{\text {th }}$ sess, UN Doc A/HRC/8/34 (13 May 2008) para 64.21.
} 
Figures 3 and 4 below examine the categories of recommendations and issues raised during Nigeria's UPR I and II. Figure 3 below examines the categories of recommendations and issues raised during Nigeria's UPR I and II. I adopted the verb-based action category developed by Professor McMahon which categorises UPR recommendations into various ranks, from recommendations requiring minimal action to the more specific ones. ${ }^{37} \mathrm{R} 1$ recommendations are those which required minimal actions such as to seek technical assistance or share experiences. R2 recommendations emphasized continuity and required the state under review to continue certain actions taken towards improving the human rights situation within their state. R3 recommendations called upon the state to consider implementing particular recommendations. Recommendations of a general character or which required the state to intensify or strengthen protection for human rights were categorised as general recommendations (R4). The recommendations which required specific action on the part of the state, for example to ratify, amend or adopt specific legislation were categorised as specific (R5) recommendations.

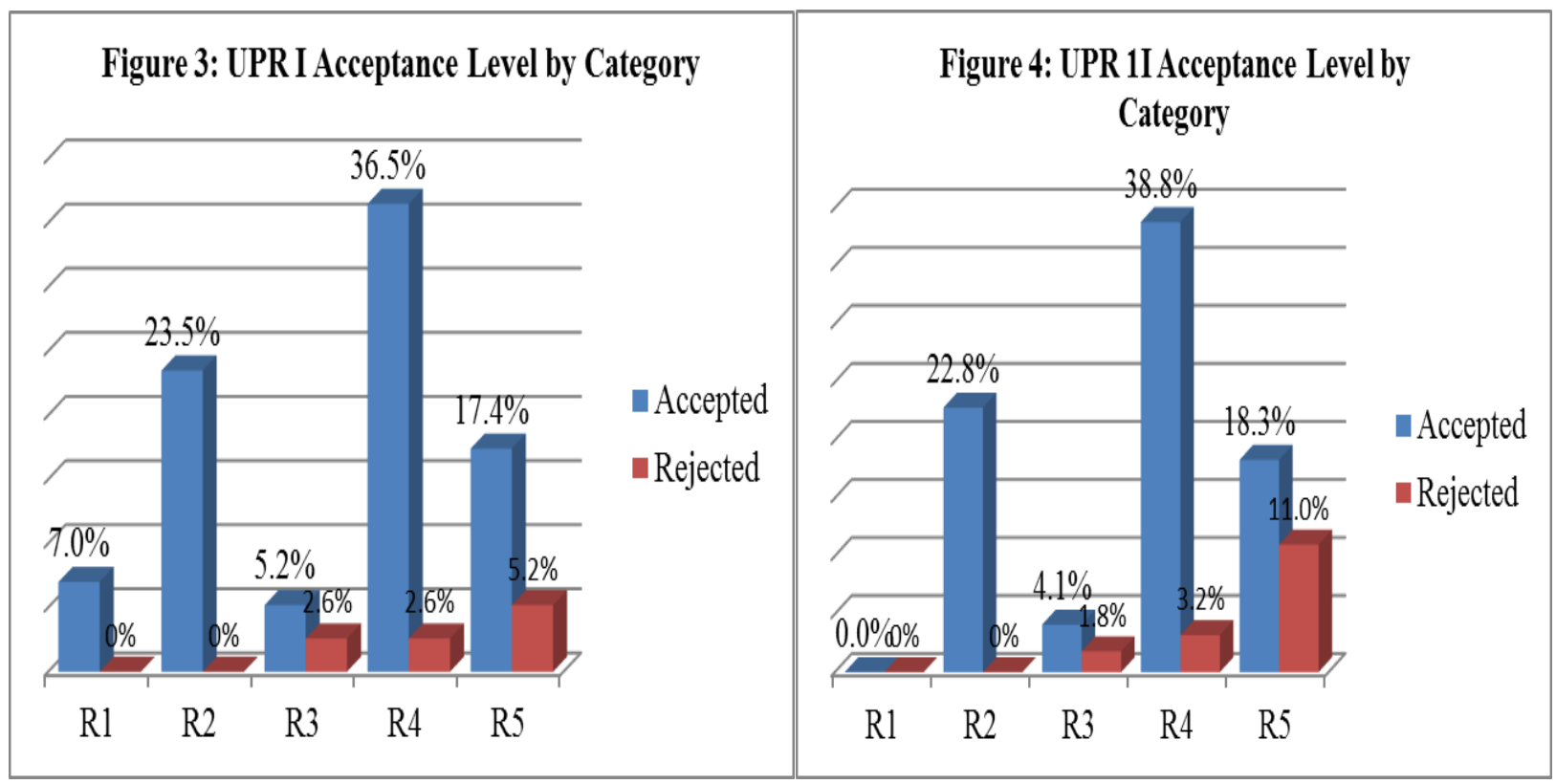

As figures 3 and 4 indicate, Nigeria was receptive to both general (R4) and specific (R5) recommendations. A majority of the recommendations accepted by Nigeria were general recommendations (R4) and this constituted about 37 and 39 percent of the total recommendations during UPR I and II respectively. The fact that such recommendations are

\footnotetext{
${ }^{37}$ Edward McMahon, (note 33 above).
} 
general does not mean that they are meaningless. Nigeria also engaged with a good number of specific recommendations but only to the extent that they did not involve issues of the death penalty and sexual orientation which have tended to be politically contentious in socio-cultural terms within Nigeria. About $23 \%$ of the 26 specific recommendations (R4) rejected by Nigeria during UPR I were on the death penalty and discrimination based on sexual orientation. Similarly, during UPR II, recommendations on the death penalty and sexual orientation accounted for $95 \%$ of the 24 specific recommendations rejected by Nigeria. This indicates a cultural relativist tendency in the engagement of Nigeria with the UPR.

However, while the Nigerian government was not receptive to recommendations on the above two issues, it was receptive to other human rights issues that dominated both cycles of its review. Table 1 below lists the top 15 issues that received recommendations during Nigeria's UPR I and II. The human rights issues on the table are clustered based on the frequency with which states made recommendations. A similar classification has been used by UPR Info and by Nigerian Human Rights Commission. ${ }^{38}$

$\underline{\text { Table } 1}$

\begin{tabular}{|c|c|c|c|c|c|c|c|}
\hline \multicolumn{4}{|c|}{ UPR I } & \multicolumn{4}{|c|}{ UPR II } \\
\hline Rank & Issue & $\begin{array}{l}\text { Total No. } \\
\text { of Recom. } \\
\text { (UPR I) }\end{array}$ & $\begin{array}{l}\% \text { of } 115 \\
\text { Recom. } \\
\text { (UPR I) }\end{array}$ & Rank & Issue & $\begin{array}{c}\text { Total No. } \\
\text { of Recom. } \\
\text { (UPR II) }\end{array}$ & $\begin{array}{c}\% \text { of } 219 \\
\text { Recom. } \\
\text { (UPR II) }\end{array}$ \\
\hline 1 & $\begin{array}{l}\text { Women's } \\
\text { Rights }\end{array}$ & 24 & 20.87 & 1 & $\begin{array}{l}\text { Rights of the } \\
\text { Child }\end{array}$ & 53 & 24.2 \\
\hline 2 & $\begin{array}{l}\text { Rights of the } \\
\text { Child }\end{array}$ & 17 & 14.78 & 2 & $\begin{array}{l}\text { Women's } \\
\text { Rights }\end{array}$ & 46 & 21 \\
\hline 3 & $\begin{array}{l}\text { Torture and } \\
\text { other CID } \\
\text { Treatment }\end{array}$ & 17 & 14.78 & 3 & $\begin{array}{l}\text { International } \\
\text { Instruments }\end{array}$ & 40 & 18.26 \\
\hline 4 & $\begin{array}{l}\text { Justice and } \\
\text { Detention }\end{array}$ & 17 & 4.78 & 4 & Death Penalty & 25 & 11.42 \\
\hline 5 & $\begin{array}{l}\text { International } \\
\text { Instruments }\end{array}$ & 13 & 11.3 & 5 & $\begin{array}{l}\text { Justice and } \\
\text { Detention }\end{array}$ & 25 & 11.42 \\
\hline 6 & Death Penalty & 12 & 10.43 & 6 & $\begin{array}{c}\text { Right to } \\
\text { Education }\end{array}$ & 23 & 10.5 \\
\hline
\end{tabular}

\footnotetext{
${ }^{38}$ UPR Info, 'Issue Categorisation' < https://www.upr-info.org/database/files/Database_Issues_explanation.pdf $>$; The National Human Rights Commission of Nigeria, Report on State of Compliance with International Minimum Standards of Human Rights by Nigeria under the Universal Periodic Review Mechanism < https://uprdoc.ohchr.org/uprweb/downloadfile.aspx?filename=556\&file=EnglishTranslation $>$.
} 


\begin{tabular}{|l|l|l|l|l|l|l|l|}
\hline 7 & Minorities & 8 & 6.96 & 7 & $\begin{array}{c}\text { Torture and } \\
\text { other CID } \\
\text { Treatment }\end{array}$ & 20 & 9.13 \\
\hline 8 & $\begin{array}{c}\text { Human Rights } \\
\text { Education and } \\
\text { Training }\end{array}$ & 8 & 6.96 & 8 & $\begin{array}{c}\text { Human Rights } \\
\text { Education and } \\
\text { Training }\end{array}$ & 17 & 7.76 \\
\hline 9 & $\begin{array}{c}\text { Technical } \\
\text { Assistance and } \\
\text { Cooperation }\end{array}$ & 8 & 6.96 & 9 & Right to Health & 17 & 6.39 \\
\hline 10 & $\begin{array}{c}\text { Right to } \\
\text { Education }\end{array}$ & 6 & 5.22 & 10 & $\begin{array}{c}\text { Freedom of } \\
\text { religion and } \\
\text { Belief }\end{array}$ & 16 & 7.31 \\
\hline 11 & $\begin{array}{c}\text { Special } \\
\text { Procedures }\end{array}$ & 5 & 4.35 & 11 & $\begin{array}{c}\text { Sexual } \\
\text { Orientation }\end{array}$ & 10 & 4.57 \\
\hline 12 & NHRI & 5 & 4.35 & 12 & Disability & 10 & 4.57 \\
\hline 13 & $\begin{array}{c}\text { Extra-judicial } \\
\text { Killing }\end{array}$ & 5 & 4.35 & 13 & Minorities & 8 & 3.65 \\
\hline 14 & Corruption & 4 & 3.48 & 14 & Trafficking & 7 & 3.2 \\
\hline 15 & Right to & 4 & 3.48 & 15 & $\begin{array}{l}\text { Violations by } \\
\text { State Agents }\end{array}$ & 6 & 2.74 \\
\hline
\end{tabular}

As indicated on the table above, the three issues which came up prominently during the UPR I of Nigeria were women's rights, the rights of the child and torture and other cruel, inhumane and degrading treatment. None of these recommendations were rejected by Nigeria. The NGO UPR I Coalition of Nigeria prioritised similar recommendations including women and children rights, torture and extra-judicial execution. ${ }^{39}$ During UPR II, women and children's rights were predominant recommendations by states to Nigeria as indicated on Table 1, as well as by NGOs. ${ }^{40}$ The government was receptive to recommendations on these prominent issues that arose during UPR I and II, and by engaging with the recommendations of its peers, the state may be indirectly engaging with NGO recommendations. It accepted recommendations such as to "[c]riminalize torture and establish an independent monitoring system of detention places," "[e]nact legislation to prohibit FGM," "Fully implement its national action plan... to meaningfully involve women in peace process and to combat gender-based violence and discrimination" and "[s]ign and ratify the Optional Protocol to the ICESCR and the Optional

\footnotetext{
${ }^{39}$ Nigeria's Civil Society Coalition on the UPR, 'Universal Periodic Review of Nigeria: A Nigeria Civil Society Coalition Report' (2008) 1-5 <https://www.upr-info.org/sites/default/files/document/nigeria/session 4 _ february 2009/js1ngauprs42009constitutionalrightsprojectetaljoint.pdf>.

${ }^{40}$ Civil Society Coalition on Minority Protection, Indigenous Peoples Issues and Children's Rights (CSCOMIC), 'Submission By Civil Society Coalition On Minority Protection, Indigenous Peoples Issues And Children's Rights' (2013) 9-10 < https://www.upr-info.org/sites/default/files/document/nigeria/session_17_october_2013/js5_upr17_nga_e main.pdf >.
} 
Protocol to the Convention on the Rights of the Child on a communications procedure". ${ }^{41}$ Such an outcome shows the state is willing to rethink their policies and consider adopting international human rights treaties as a result of constructive dialogue and their participation in a cooperative mechanism, but also depending on whether the outcome was followed up.

While sexual orientation did not feature among the top 15 issues raised during the review of Nigeria, the death penalty came up among the top six issues raised during both cycles of Nigeria's review. Recommendations on the death penalty represented about $10 \%$ of the total recommendations made during UPR I and about $11 \%$ of the recommendations made during UPR II. This underlines the importance of the death penalty in the review of Nigeria which has across both reviews gained more prominence (from $6^{\text {th }}$ to $4^{\text {th }}$ position). The Nigerian UPR delegation rejected all the recommendations during UPR I and II which directly called for the abolition of the death penalty except the UPR I recommendations by Argentina and Benin that Nigeria considers the possibility of abolishing the death penalty in the near future. ${ }^{42}$ This demonstrates the limits of Nigeria's receptiveness to particular UPR recommendation.

\section{THE EXTENT OF NIGERIA'S IMPLEMENTATION OF UPR RECOMMENDATIONS}

This section examines the extent to which Nigeria implemented its UPR commitments and the compliance gap between the accepted and the implemented commitments. ${ }^{43}$ It argues that the number of full and partially implemented recommendations underscore the potential of the UPR process to contribute to either fully effect or trigger domestic human rights changes. While the wide decoupling gap between the implemented recommendations and accepted recommendations signals that the government needs to effectively engage with the mechanism, I argue that acculturation can narrow the gap overtime through the internal and external audience effects generated by effective NGO engagement.

\section{III.1 How Implementation was Measured}

\footnotetext{
${ }^{41}$ Human Rights Council, Report of the Working Group on the Universal Periodic Review - Nigeria, $25^{\text {th }}$ sess, Agenda Item 6, UN Doc A/HRC/25/6 (16 December 2013) ('HRC UPR II Report -Nigeria'), paras 135.73, 135.56 and 135.1 .

${ }^{42}$ Human Rights Council, Report of the Human Rights Council on its twenty-fifth session, $25^{\text {th }}$ sess, UN Doc A/HRC/25/2 (27 May 2014), paras 1 and 14.

${ }^{43}$ Since UPR II implementation stage was still ongoing, I limited the analysis to UPR I.
} 
A coalition of 39 domestic NGOs known as Human Rights Agenda Network (HRAN) provided responses on each of the recommendations in their report. ${ }^{44}$ The Nigerian National Commission for Human Rights (NCHR) also provided commentary on the Nigeria's UPR I recommendations and the extent of state compliance. ${ }^{45}$ Amnesty International (AI), Commonwealth Human Rights Initiative (CHRI), Centre for Reproductive Rights (CRR), BAOBAB for Women's Human Rights (BWHR) and Cleen Foundation (CF) also provided relevant useful responses to UPR Info which will be used here. The responses of the Nigeria government were extracted from its UPR II national report which commented on the extent of their implementation of UPR I recommendations.

I use the Implementation Recommendation Index (IRI) to measure Nigeria's implementation of its UPR I recommendations. The IRI is an index developed by UPR Info which brings together an average of stakeholders' responses. It shows the implementation level of states for recommendations that were received by the state during the UPR review. The value of this index is that it takes in to account stakeholders' responses and any dispute which they may have over the implementation of a recommendation. Implementation is not binary. This index captures three stages of implementation. When all stakeholders agree that a recommendation was fully implemented the recommendation is scored 1 . Whenever a stakeholder claimed that no aspect of a recommendation was been implemented, the index score is 0 . The score is 0.75 when the state under review claims that the recommendation has been fully implemented but a stakeholder says it has only been partially implemented. In some cases, partial implementation of a recommendation was indicative that an action was started by the state such as introducing a bill but the final action, enacting a law, was not realised. The average of the scores is then transformed into an implementation level where 0-0.32 = Not Implemented, 0.33-0.65 = Partially Implemented and 0.66-1 = Fully Implemented.

A major challenge in measuring state UPR implementation is that the UPR is a dynamic and on-going process. As such recommendations which this index may classify as implemented or not implemented may have subsequently changed. To control the changes which may

\footnotetext{
${ }^{44}$ Human Rights Agenda Network (HRAN) 'Written Submission to Universal Periodic Review of Nigeria, OctNov 2013' (2013) https://uprdoc.ohchr.org/uprweb/downloadfile.aspx?filename=148\&file=EnglishTranslation>. $\begin{array}{cccc}45 & \text { Full version } & \text { available } & \text { at }\end{array}$ https://uprdoc.ohchr.org/uprweb/downloadfile.aspx?filename=556\&file=Annexe1 $>$.
} 
subsequently occur, the implementation measured is restricted within the implementation time frame allocated for each review. Another major difficulty encountered in indexing the implementation level of Nigeria's UPR I recommendations was the fact that a recommendation sometimes embodied more than 1 recommendations. As such the full implementation of one recommendation but not the other resulted in a partial implementation level. The implementation time for Nigeria to implement its UPR I recommendations ran from February 2009 when the UPR working group adopted its UPR report till July 2013 when it submitted its UPR II report.

In addition, this research is aware of the difficulty attempting to establish a precise causal link between UPR recommendations and the actions of states. This is difficult due since changes in the human rights practices of states can be motivated by multiple factors. However, the influence of the UPR recommendations is measurable with some confidence by analysing both state and NGO implementation reports to determine the extent to which the UPR contributed to human rights change within states. Other relevant studies on the UPR accept and use similar methodology. 46

\section{III.2 Extent of Implementation}

Within the implementation period Nigeria, implemented either fully or partially about $43 \%$ of the commitment made during its UPR I. With regard to the pledges and commitments it made to the HRC, Nigeria fulfilled some of them. From among the stakeholders, only the National Human Rights Commission (NHRC) in its UPR II report ${ }^{47}$ directly addressed the level of implementation. However, some of the pledges and commitments made by Nigeria corresponded to some of the recommendations made by states during Nigeria's UPR I review. ${ }^{48}$ Other stakeholders indirectly provided responses to the pledges in their reports on Nigeria's implementation of UPR recommendations. To comply with some of its pledges and

\footnotetext{
${ }^{46}$ See Subhas Gujadhur and Marc Limon, Towards the Third Cycle of the UPR: Stick or Twist? Lessons Learnt from the first ten years of the Universal Periodic Review (Universal Rights Group, 2016) 35-7; UPR Info, 'Universal Periodic Review: On the Road to Implementation' (2012) $63<$ <ttp://www.uprinfo.org/sites/default/files/general-document/pdf/2012 on the road to implementation.pdf $>$.

47 See National Human Rights Commission of Nigeria, 'Report on State of Compliance with International Minimum Standards of Human Rights by Nigeria under the Universal Periodic Review Mechanism' < https://uprdoc.ohchr.org/uprweb/downloadfile.aspx?filename=556\&file=EnglishTranslation $>2$.

${ }^{48}$ For example Nigeria undertook to accelerate the process full domestication of international human rights treaties and this correspond to its second UPR I recommendation made by Ghana, Norway, Niger, Algeria and Brazil. For details on the pledges and commitments made by Nigeria see OHCHR, 'Human Rights Council: Nigeria's Voluntary Pledges and Commitments' www.un.org/ga/60/elect/hrc/nigeria.pdf.
} 
commitments, Nigeria ratified the ICRMW; deposited its National Action Plan (NAP) which amended the National Human Rights Commission Act to grant the NHRC independence, investigative and enforcement powers; and diplomatically intervened to restore peace and democracy in Guinea, Guinea Bissau and Mali. ${ }^{49}$

On the UPR recommendations, actions were triggered on some at the end of UPR I. Out of a summary of 30 recommendations accepted by Nigeria, about $10 \%$ were fully implemented (FI), about $33 \%$ were partially implemented (PI), about 53\% was not implemented (NI) and about $3 \%$ of the recommendations were not assessed because UPR stakeholders did not provide any information in relation to their implementation. Figure 5 below represents percentages of the recommendations that were FI, PI and NI.

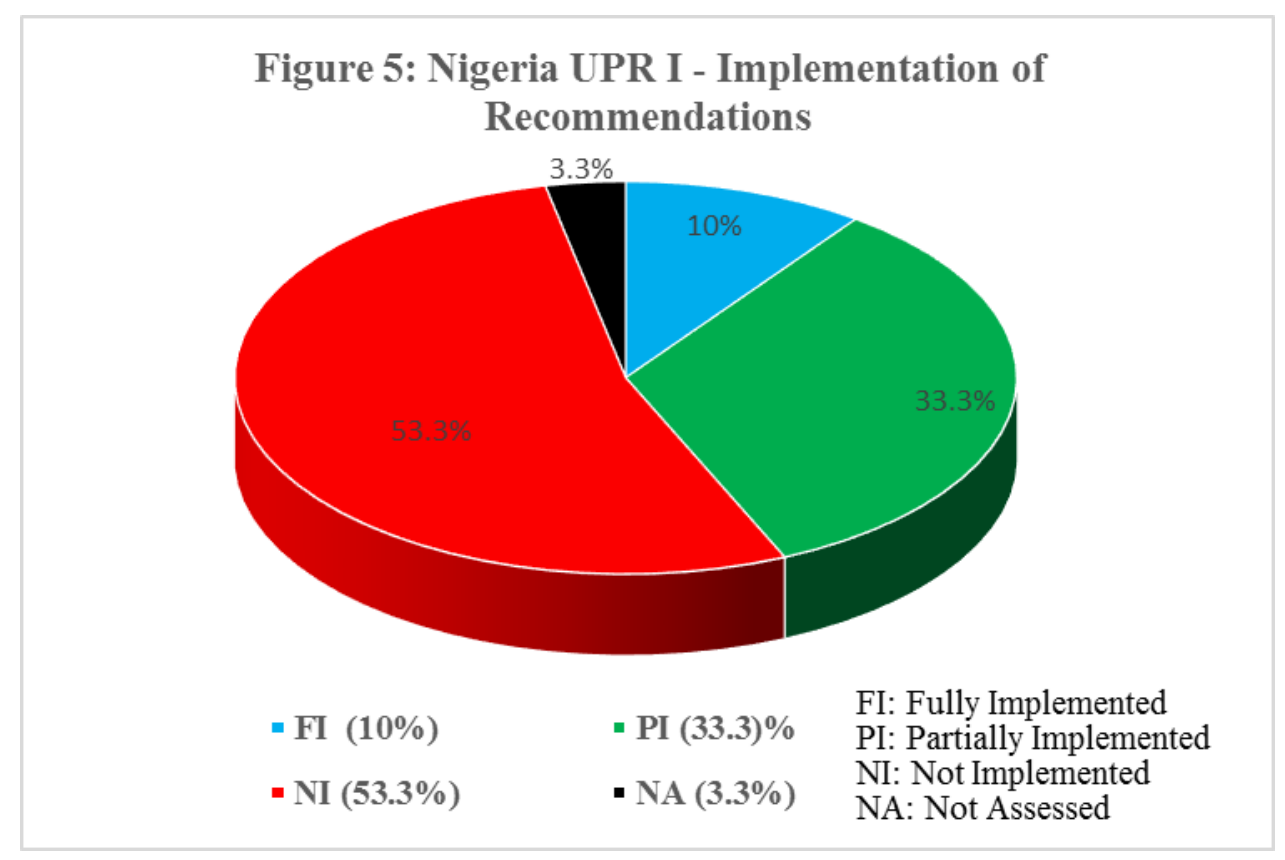

As indicated above, about $43 \%$ of the UPR recommendations Nigeria accepted was either fully or partially implemented while about $53 \%$ was not implemented. On the FI recommendations, the state, the NHRC, domestic and some international NGOs agreed on the full implementation of some of these recommendations. For example the state, ${ }^{50} \mathrm{NCHR}^{51}$ and Amnesty

\footnotetext{
${ }^{49}$ See National Human Rights Commission of Nigeria (note 47 above).

${ }^{50}$ HRC UPR II State Report - Nigeria (note 41 above) para 32.

${ }^{51}$ National Human Rights Commission of Nigeria, 'National Human Rights Commission Table of Commentary on 2009 UPR recommendations and the extent of Compliance'< https://uprdoc.ohchr.org/uprweb/downloadfile.aspx?filename=556\&file=Annexe1 $>$. 
International $^{52}$ were in agreement that recommendation 4 relating to the amendment of the Human Rights Commission Act to grant the NHRC independence, investigative and enforcement powers had been fully implemented. This greatly contributed to the Commission attaining an 'A' status at the International Coordinating Committee of Human Rights a year after. Similarly, the response of Human Rights Agenda Network (HRAN), a leading domestic NGO, ${ }^{53}$ did not dispute that the government had continued to invest in education within the relevant time. As such the recommendation in this regard was fully implemented.

On the partially implemented recommendations, the government of Nigeria had triggered the process of implementation on some of the recommendations even though not yet completed. In some of the recommendations, both the state and the stakeholders agreed that the recommendation had only been partially implemented. On others there were dispute not only between the state and the stakeholders but equally among the stakeholders. For example, HRAN $^{54}, \mathrm{NHRC}^{55}$ and the government of Nigeria ${ }^{56}$ all accepted that recommendation 1 relating to accession to human rights instruments to which Nigeria is not yet a party had only been partially implemented. This featured among the top five recommendations that were made to Nigeria (See Table 1 above). Recommendation 28 required the government to take steps to bolster the national health system. While the $\mathrm{NHRC}^{57}$ and the state ${ }^{58}$ agreed that steps have been taken in this regard, HRAN's response was not in agreement with this. ${ }^{59}$ Relevant studies on the Nigerian health system indicated that the system was deplorable and the attitude of health care workers towards patients was very poor. ${ }^{60}$

\footnotetext{
52 Amnesty International (AI), 'Universal Periodic Review of Nigeria: Submission by Amnesty International, 17th Session Of The UPR Working Group, October 2013 (July 2013) IOR 41/011/2013, 2 < https://uprdoc.ohchr.org/uprweb/downloadfile.aspx?filename=557\&file=EnglishTranslation $>$.

53 A coalition of 39 domestic NGOs. See Human Rights Agenda Network (HRAN) 'Written Submission to Universal Periodic Review of Nigeria, Oct-Nov 2013' (2013) < https://uprdoc.ohchr.org/uprweb/downloadfile.aspx?filename=148\&file=EnglishTranslation 8>.

${ }^{54}$ Ibid 2.

${ }^{55}$ National Human Rights Commission of Nigeria, 'National Human Rights Commission Table of Commentary on 2009 UPR recommendations and the extent of Compliance' above $\mathrm{n} 51$, para 1.

${ }^{56}$ HRC UPR II State Report - Nigeria (note 41 above), para 22.

57 The National Human Rights Commission of Nigeria, above n 51, [28]

${ }^{58}$ HRC UPR II State Report - Nigeria (note 41 above), [102].

${ }^{59}$ Human Rights Agenda Network (HRAN), above n 53, 7.

${ }^{60}$ See Ajovi Scott-Emuakpor, 'The Evolution of Health Care Systems in Nigeria: Which way Forward in the Twenty-First Century’ (2010) 51(2) Nigerian Medical Journal 53; Nigeria National Human Rights Commission, Research Study on Human Rights and Maternal Mortality: Pilot Study on Women's Access to Health Care Facilities in the Six Area Council of the Federal Capital Territory (FCT), Abuja (National Human Rights Commission, 2015) 29-30.
} 
The few recommendations that were fully implemented covered issues on the National Human Rights Institution, education and raising awareness among cultural and religious leaders. Many of the recommendations which had not been implemented concerned issues such as justice and detention, women's rights, torture and extra-judicial executions. With the exception of extrajudicial executions, they were among the 5 prominent issues that received the most recommendations during Nigeria's UPR 1, and constituted about $42 \%$ of the total recommendations made to Nigeria during UPR I (See Table 4.1 above). The relevance and effects of the non-implementation of these four issues is examined below. While the state took some steps towards implementation outside the UPR I implementation timeframe, these issues still raise serious human rights concern in Nigeria.

\section{III.2.1 Justice and Detention}

Access to justice and detention conditions have been persistent problems in Nigeria. Mary Robinson, former UN High Commissioner for Human Rights, pointed out that the "way in which justice is administered is a key benchmark of a country's commitment to human rights". ${ }^{61}$ The right to fair trial and freedom from arbitrary arrest are enshrined in sections 35 and 36 of the 1999 Constitution of Nigeria but these provisions have largely not been implemented. ${ }^{62}$ In its 2010 report on the state of human rights in Nigeria, the Nigerian NHRC recommended that the justice administration should be overhauled. ${ }^{63}$ A 2012 national prison audit undertaken by the Nigerian NHRC highlighted major issues. The prisons were old and dilapidated, congested and appalling prison facilities. ${ }^{64}$ More than 18,000 detainees had spent a long time awaiting trial with some having spent up to 16 years awaiting trial. ${ }^{65}$ Another prison audit exercise undertaken by the NHRC in 2014 at the Kuje Medium Security Prison, Abuja, reported that 86 detainees have been awaiting trial for at least 3years. ${ }^{66}$ In 2009 there were 71 cases of unlawful arrest and detention reported by the NHRC. In 2010, this number rose to 497

\footnotetext{
${ }^{61}$ Mary Robertson, A Voice for Human Rights (University of Pennsylvania Press, 2010) 255

${ }^{62}$ Nigeria National Human Rights Commission, The State of Human Rights in Nigeria: 2009-2010 (National Human Rights Commission, 2010) 60.

${ }^{63}$ Ibid.

${ }^{64}$ The audit report revealed that out of 50,645 persons detained, about $70 \%$ were awaiting trial. See The National Human Rights Commission Nigeria, National Prison Audit 2012 (The National Human Rights Commission, 2014) 3-11.

${ }^{65}$ The audit report revealed that out of 50,645 persons detained, about $70 \%$ were awaiting trial. See The National Human Rights Commission Nigeria, National Prison Audit 2012 (The National Human Rights Commission, 2014) 5 and 17.

${ }^{66}$ The National Human Rights Commission Nigeria, Annual Report 2014 (National Human Rights Commission, 2014) 87-8.
} 
and in 2012, there were 3,642 reported cases. ${ }^{67}$ While these increase numbers may simply reflect an increase in reporting rather than occurrences, they do unveil the underlying problem and underscore the relevance of the recommendations which states made during Nigeria's UPR I. France recommended that Nigeria should "[i]mprove the conditions of detention within prisons, access to health and the respect for the most elementary rights of detainees". ${ }^{68}$ The UK recommended that Nigeria "[t]ake action to tackle the backlog of prisoners who have been detained without trial or beyond the end of their sentence" 69 and Belgium recommended that Nigeria "[t]ake specific measures in order to address the dis-functioning of the judicial system and the lack of internal and external monitoring of the police". ${ }^{70}$ As indicated on Table 1 above, this was the fourth most prominent issue during Nigeria's UPR I, accounting for about $5 \%$ of the total recommendations.

However, in terms of implementation, very little progress was made by the state within the implementation period. There were efforts to reform the criminal justice system with new judges appointed at all levels. ${ }^{71}$ However, according to the NHRC, Nigeria's pre-trial system continues to violate human rights, the prison system is below UN Standard Minimum Rules for the Treatment of Prisoners and police oversight bodies remain weak and unable to monitor the excesses of the police. ${ }^{72}$ Nevertheless, in 2015, the Administration of Criminal Justice Act was enacted to reform the criminal justice sector. ${ }^{73}$ While this falls outside the implementation period for UPR I, it lends more support to the acculturation argument (examined in the section 4 below) which underscores the potential for the UPR to, over time, influence changes within states.

\section{III.2.2 Women's Rights}

According to the Nigerian NHRC, reports of violence against women grew by alarming proportions within the first cycle of the UPR. In 2009, the NHRC received 30 reported cases

\footnotetext{
${ }^{67}$ After 2012, there was decline in the number of cases reported. See ibid, 52.

${ }^{68}$ HRC UPR I Report - Nigeria (note 27 above), para 41.

${ }^{69}$ Ibid para 25.

${ }^{70}$ Ibid para 64.

${ }^{71}$ See The National Human Rights Commission of Nigeria, above n 51.

72 Ibid.

${ }^{73}$ Administration of Criminal Justice Act, 2015 (Nigeria).
} 
of domestic violence. ${ }^{74}$ In 2010, this number rose to 325 and in 2011 and 2012, there were over 2,500 reported cases of domestic violence. ${ }^{75}$ Also, Nigeria has the highest number of reported female genital mutilation (FGM) cases in the world, accounting for about one-quarter of the estimated 115-130 million circumcised women worldwide. ${ }^{76}$ Therefore states were justified to place women's rights issues at the top of Nigeria's UPR I recommendations, receiving more recommendations (about 21\%) than any other issue (see Table 1 above). Many of these recommendations required the Nigerian government to implement legislation against sexual and gender based violence, undertake awareness raising campaigns to eradicate FGM and enact legislation to prohibit FGM. ${ }^{77}$

Implementing these recommendations within the UPR I implementation period proved challenging for the state. As observed by the NHRC, few state governments within Nigeria enacted laws on FGM but there was no federal legislation on FGM, discrimination against women, child marriage and betrothal or gender based violence. ${ }^{78}$ Many of these recommendations which were not implemented were vital in improving the human rights situation on the ground. However, as earlier noted, over time some of these recommendations have been implemented, even though outside the UPR I implementation timeframe. In 2015, the Violence against Persons Prohibition Act was passed into federal law. This Act specifically addresses violence against women including FGM in Article 6 and prescribes a penalty of up to 4 years imprisonment and or a fine. ${ }^{79}$ While the Act can be criticised for its failure to recognise the particular vulnerability of women to violence by replacing the word 'women' with "persons", it nevertheless demonstrates a positive move by the government of Nigeria in its fight against violence against women and other vulnerable persons. This is supplemented by a 4 year National Policy and Plan of Action for the Elimination of FGM in Nigeria which identifies and engages key stakeholders at the federal, state and community levels. ${ }^{80}$ However,

\footnotetext{
74 This continues to prevail despite section 46 (1) of the 1999 Constitution of Nigeria which protects women against violence and discrimination. See The National Human Rights Commission Nigeria, Annual Report 2014, above n 66, 52 .

75 Ibid 52.

${ }^{76}$ NPC and UNICEF Nigeria, 'Children's and Women's right in Nigeria: A wake up call - Situation Assessment and Analysis of Harmful Traditional Practice (FGM)’ (Abuja 2001) 195-200.

${ }^{77}$ HRC UPR I Report - Nigeria (note 27 above), paras 18, 62, 71, 77 and 83.

${ }^{78}$ See The National Human Rights Commission of Nigeria, above n 51, para 18.

${ }^{79}$ Nigeria: Violence Against Persons (Prohibition) Act, 2015 (VAPP) [Nigeria] (25 May 2015).

${ }^{80}$ Federal Ministry of Health Abuja, National Policy and Plan of Action for the Elimination of Federal Genital mutilation in Nigeria 2013-2017 (Federal Ministry of Health Abuja, 2013).
} 
there has been no evidence of their enforcement and reports indicate that the practice of FGM "remain widespread, with low rates of reporting". 81

\section{III.2.3 Torture, Cruel Inhuman and Degrading Treatment}

In 2006, the UN Special Rapporteur on Extra-Judicial, Summary or Arbitrary Executions observed that torture was an intrinsic part of law enforcement methods in Nigeria. ${ }^{82}$ Section 34 (1) of the 1999 Constitution of Nigeria expressly provides that "no person shall be subjected to torture or to inhuman or degrading treatmen". ${ }^{83}$ Furthermore, Article 4 of the Convention against Torture provides that "[e]ach state party shall ensure that all acts of torture are offences under its criminal law". ${ }^{84}$ This is a non-derogable right and a peremptory norm of international law. Despite these, the number of cases reported to the Nigerian NHRC between 2009 and 2012 was on the rise. In 2009, the number of reported cases was at 94 but in 2010 the number had risen to 1,403 and in 2012 the number stood at 2,230. ${ }^{85}$ It was in this light that states like Benin, Ukraine, The Netherlands and Denmark, recommended that Nigeria should "establish a national preventive mechanism to align itself with its neighbours positive practices"; "[s]tep up its efforts to halt torture and ill-treatment"; adopt legislative measures to prevent and prosecute acts of torture and other ill-treatment; and "[p]revent using cruel, inhuman and degrading punishment". ${ }^{86}$ These recommendations accounted for about $15 \%$ of the total recommendations made to Nigeria during UPR I.

With regard to their implementation, in 2009, Nigeria set up the National Committee Against Torture (NCAT) as a national preventative mechanism. ${ }^{87}$ The NCAT is mandated amongst other things to receive and consider complaints on torture; conduct visits to places of detention

\footnotetext{
${ }^{81}$ Immigration and Refugee Board of Canada, 'Nigeria: Prevalence of female genital mutilation (FGM) among the Urhobo, including the consequences for refusing to undergo this procedure, particularly pregnant women; state protection available (2014-March 2015)' (2015) http://www.refworld.org/docid/56498d834.html.

${ }^{82}$ UN Human Rights Council, Report of the Special Rapporteur on Torture and Other Cruel, Inhuman or Degrading Treatment or Punishment, Manfred Nowak: addendum: mission to Nigeria (4 to 10 March 2007), UN Doc A/HRC/7/3/Add.4 (22 November 2007) para 40.

${ }^{83}$ Constitution of the Federal Republic of Nigeria (1999), s 34 (1).

${ }^{84}$ Convention Against Torture and Other Cruel, Inhuman or Degrading Treatment or Punishment, opened for signature 10 December 1984, UNTS 1465 (entered into force 26 June 1987); Nigeria ratified the Optional Protocol of the Convention against Torture (OPCAT) in 2009. See also Article 5 of the African Charter on Human and Peoples' Rights.

${ }^{85}$ The National Human Rights Commission Nigeria, Annual Report 2013 (National Human Rights Commission, 2013).

${ }^{86}$ HRC UPR I Report - Nigeria (note 27 above), para 103.1.

87 Federal Ministry of Justice (Nigeria), 'Mandate of the National Committee on Torture' $(2010)<$ http://www.apt.ch/content/files/npm/africa/Nigeria_NPM_ToR.pdf $>$;
} 
and examine allegations of torture therein; review the treatment of persons in detention with a view to prevent torture; develop a national anti-torture policy and propose anti-torture legislation. ${ }^{88}$ The NCAT has partnered with the NHRC to organise training workshops and sensitise relevant actors on the UN Convention against Torture (CAT) and its Optional Protocol. $^{89}$

Despite these efforts, torture continues to persist. The Nigerian Criminal and Penal code does not explicitly prohibit torture and the NCAT does not have investigatory or prosecutorial powers. ${ }^{90}$ This is arguably inconsistent with the constitutional provision and international obligation earlier mentioned. Force Order 237 of Nigeria's Police Regulations contributes to the ongoing use of torture by permitting police officers to shoot detainees and suspects who attempt to escape or avoid arrest, regardless of whether they pose a threat to life. ${ }^{91}$ Nevertheless, the work undertaken by the NCAT is a significant step. There has recently been a decline in the number of reported cases of torture and other cruel inhuman and degrading treatment between 2012 and 2014, from 1920 reported cases to below $400 .{ }^{92}$ But Nigeria is yet to recognise the competence of the Committee against Torture to receive communications from individuals under article 22 of CAT.

It can be observed from the above analysis that the Nigerian government engaged with the implementation of many of its UPR I recommendations. This underscores the potential for cooperative mechanisms to contribute to human rights changes within states. As explained by Elvira Domínguez Redondo, "those in charge of human rights mechanisms, scholars and practitioners tend to neglect the potential value of cooperative approaches to human rights implementation and focus instead on the confrontational approaches"93 While this section demonstrates the potential for the UPR to improve the human rights situation on the ground, it examined decoupling gap between the recommendations accepted on the one hand and those implemented on the other (including both FI and PI). This is represented by more than $50 \%$ of

\footnotetext{
${ }^{88}$ Ibid; National Committee against Torture, 'Fourth Quarterly Report of the National Committee against Torture to the United Nations Sub Committee against Torture in Geneva, Switzerland (2015) < http://www.ohchr.org/Documents/HRBodies/OPCAT/NPM/Nigeria2014.pdf>.

${ }^{89}$ The National Human Rights Commission Nigeria, Annual Report 2014, above n 66, 63-4.

${ }^{90}$ See The National Human Rights Commission of Nigeria, above n 51, para 22.

91 See Federal Ministry of Justice (Nigeria), 'Mandate of the National Committee on Torture' $(2010)<$ http://www.apt.ch/content/files/npm/africa/Nigeria NPM ToR.pdf $>$;

92 The National Human Rights Commission Nigeria, Annual Report 2014, above n 66, 52.

${ }^{93}$ Elvira Domínguez Redondo, 'The Universal Periodic Review-Is There Life Beyond Naming and Shaming in Human Rights Implementation?’ (2012) 4 New Zealand Law Review 673, 683.
} 
recommendations not implemented within the implementation time periodic. As earlier indicated, my analysis does not assert a direct causal link between a state's action and specific UPR recommendations. Rather, it considers the extent to which the UPR contributed to the realisation of human rights changes within states. The implementation of recommendations, especially on justice and detention, women's rights and torture, as examined above still represent significant challenges in Nigeria, which, as argued in the next section, can be narrowed over time.

\section{ACCULTURATION AND ITS EFFECTS ON NIGERIA'S UPR ENGAGEMENT}

\subsection{The Theory of Acculturation}

According to Ryan Goodman and Derek Jinks, acculturation is 'the general process by which actors adopt the beliefs and behavioural patterns of the surrounding culture, without actively assessing either the merits of those beliefs and behaviours or the material costs and benefits of conforming to them. ${ }^{94}$ The theory of acculturation calls into question the view that compliance with human rights norms is best induced by the exercise of coercive power or by binding decisions emanating from human rights monitoring institutions. ${ }^{95}$ Central to the acculturation theory is that power is not merely prohibitive, material and centralised but also productive, cultural and diffuse. ${ }^{96}$ Goodman and Jinks argue that mechanisms based on coercion are inadequate because coercion 'fails to grasp the complexity of the social environment within which states act. ${ }^{97}$ Monitoring and reporting are highly effective and important functions in an acculturation-based institutional regime, while sanctions and binding decisions are potentially counterproductive. ${ }^{98}$ The acculturation approach shows preference for 'soft' mechanisms but does not call for a complete abandonment of coercive mechanisms. Rather, it

\footnotetext{
${ }^{94}$ Ryan Goodman and Derek Jinks, Socializing States: Promoting Human Rights through International Law (Oxford University Press, 2013) 22.

${ }^{95}$ See De Frouville (note 10 above) 254; Nowak, 'It's Time for a World Court of Human Rights' (note 14 above) 23.

${ }^{96}$ Ryan Goodman and Derek Jinks, Socializing States: Promoting Human Rights through International Law (note 94 above) 122.

${ }^{97}$ See Ryan Goodman and Derek Jinks, 'How to Influence States: Socialization and International Human Rights Law' (2004) 54 Duke Law Journal 621, 625.

${ }^{98}$ Ibid 699.
} 
argues that acculturation, like coercion, is more likely to succeed under certain conditions or when combined with other mechanisms. ${ }^{99}$

The 'microprocesses' of acculturation which include 'mimicry' and 'identity' propel cognitive and social pressures which drive a state to adopt socially legitimate attitudes, beliefs and behaviours. ${ }^{100}$ Mimicry relates to states copying the behaviour of other states. Acculturation involves a social pressure to conform to the behaviour of a reference group and conformity produces mimicry. This mimicry model proposed by Goodman and Jinks has been applied to other areas of international law. ${ }^{101}$ In particular, James Munro argues that acculturation explained the creation of the ASEAN Intergovernmental Commission on Human Rights (AICHR), whereby ASEAN states copied other states and regional organisations in the process and effectively mimicked a pattern of global behaviour. ${ }^{102}$

Goodman and Jinks argue that 'identification' is the touchstone of the theory of acculturation. ${ }^{103}$ By identifying themselves with a reference group, states generate varying degrees of social and cognitive pressures to conform to the norms of that group. ${ }^{104}$ The social environment within which states act propels internal cognitive and social pressures which drive a state to adopt socially legitimate attitudes and beliefs. In his review on the theory of acculturation, Harold Koh validates the theory of acculturation as a case study of internalisation through socialisation. ${ }^{105} \mathrm{He}$ argues that by focusing on acculturation over coercion, Goodman and Jinks unmask a new approach to influence state compliance with human rights law through a 'complex interaction between process and ideas.' 106

The UPR mechanism shows the power of peer pressure and global culture in enforcing human rights law through state influence. Acculturation particularly favours the UPR mechanism because it is based on peer review and not configured to involve a selected group of insiders

\footnotetext{
99 Ryan Goodman and Derek Jinks, 'International Law and State Socialisation: Conceptual, Empirical and Normative Challenges' (2005) 54 Duke Law Journal 983, 991.

${ }^{100}$ Goodman and Jinks, 'How to Influence States: Socialisation and International Human Rights Law' (note 97 above) 639-42.

${ }^{101}$ Michael Stein and Alex Geisinger, 'A Theory of Expressive International Law' (2007) 60 Vanderbilt Law Review 77.

102 James Munro, 'The relationship between the origins and regime design of the ASEAN Intergovernmental Commission on Human Rights (AICHR)' (2011) 15 (8) The International Journal of Human Rights 1185.

${ }^{103}$ Goodman and Jinks, 'How to Influence States: Socialisation and International Human Rights Law' (note 97 above) 626 .

104 Ibid.

${ }^{105}$ Harold Hongju Koh, 'Internalisation through Socialisation' (2005) 54 Duke Law Journal 975, 977.

106 Ibid.
} 
(experts), examining or reviewing those considered as outsiders (states). This helps to dispel the perception of 'us' versus 'them'. According to Goodman and Jinks, the cognitive and social pressures generated by the acculturation micro process of identification is more effective when an International Governmental Organisation provides universal membership and subjects all member states to review. ${ }^{107}$ Maria Stavropoulou has examined the acculturation theory in the context of refugee protection. She found that refugee protection regimes could explore the benefits of inclusive membership through the creation of additional fora building on acculturation techniques. ${ }^{108}$ The UPR mechanism is inclusive, cooperative and collaborative, and has in two cycles of the UPR achieved a $100 \%$ state cooperation rate. ${ }^{109}$ The cornerstone principles of the UPR - universality and cooperation, can be effective in harnessing the social and cognitive pressures associated with acculturation which can facilitate the social learning process of states as they engage with the UPR process. However, as observed by Goodman and Jinks, acculturation can produce a 'decoupling' situation where public conformity with human rights norms is disconnected from local practice. ${ }^{110}$

\subsection{Narrowing Nigeria's UPR Implementation Gap: The Impact of Acculturation}

Nigeria has made major commitments in its UPR engagement and is a party to major international human rights instruments. Despite this, implementation has often proved problematic. As the findings above indicate, more than half of the UPR I recommendations were not implemented by Nigeria. Narrowing the gap between a government's human rights rhetoric and its human rights actions is crucial for the human rights situation on the ground to be improved. But can this gap be narrowed?

The gap between compelling human rights rhetoric and meaningful political change is often a sizeable one. ${ }^{111}$ However, it is arguable that over time, shallow or rhetorical human rights commitments will resonate to deeper commitments through a process that Jon Elster refers to

\footnotetext{
${ }^{107}$ Ryan Goodman and Derek Jinks, Socializing States: Promoting Human Rights through International Law (note 94 above) 103.

108 Maria Stavropoulou, 'Influencing State Behaviour for Refugee Protection: UNHCHR and the Design of the Refugee Protection Regime’ (UNHCHR Research Paper No. 154, The UN Refugee Agency, 2008) 9-15.

${ }^{109}$ With the exception of Israel which temporarily boycotted its UPR II in January 2013, all UN member states have been reviewed in the two cycles of the UPR. In October 2013, Israel returned and undertook its UPR II.

${ }^{110}$ Goodman and Jinks, Socializing States: Promoting Human Rights through International Law (note 94 above) 140.

${ }^{111}$ Emilie M Hafner-Burton, 'Human Rights Institutions: Rhetoric and Efficacy' (2007) 44(4) Journal of Peace Research 379, 382.
} 
as the "civilizing force of hypocrisy". ${ }^{112}$ Elster reasoned that rhetorical commitments, though hypocritically made, can lead to some positive outcomes over time because an actor would hardly deviate from the principled position to which he has publicly committed himself. ${ }^{113}$ States respond to global cultural forces just like individuals and organisations respond to cultural forces within their wider environment. By identifying themselves with a reference group, states generate varying degrees of social and cognitive pressures to conform to the norms of that group. ${ }^{114}$ Identification as a microprocess of acculturation has been exploited to drive states to make human rights commitments. Identification occurs "when an individual accepts influence because he wants to establish or maintain a satisfying relationship with another person or group." 115 The social environments within which states act propel internal cognitive and social pressures which drive states to adopt socially legitimate attitudes and beliefs. ${ }^{116}$ The interest of Nigeria to identify itself with the cooperative and inclusive UPR mechanism, can over time facilitate its acculturation.

In the analysis above on Nigeria's UPR engagement, acculturation through identification was evident in several ways. Identifying itself with the African Group generated internal social and cognitive pressures which induced Nigeria to accept a high percentage of recommendations from its referenced group. ${ }^{117}$ While acceptance of UPR recommendations does not yield automatic implementation, it is a positive step towards implementation. While some may see the existence of this regional alliance as detrimental to the UPR process, ${ }^{118}$ I argue, it could favour the process of acculturation. States may tend to be more receptive to sensitive recommendations coming from the regional group they identify with, than from other groups. An example of the power of identification was evident during Nigeria's review. During UPR

\footnotetext{
112 Jon Elster, 'Deliberation and Constitution Making' in Jon Elster (ed), Deliberative Democracy (Cambridge University Press, 1998) 111.

${ }^{113}$ Ibid 104.

${ }^{114}$ Ibid 4.

${ }^{115}$ Herbert C Kelman, 'Compliance, Emulation, and Internalization: Three Processes of Attitude Change' (1958) 51(2) Journal of Conflict Resolution 53.

${ }^{116}$ For example, within the framework of the UPR, even though China rejected all its UPR I recommendations relating to the abolition of the death penalty, it thereafter reduced the scope of its application by excluding 13 nonviolent economic crimes. See Dui Hua, 'NGO Submission for the Universal Periodic Review of the People's Republic of China' (March 2013) para 16; It is however important to note that the scope of the application of the death penalty in China is still very high.

${ }^{117}$ See Figures 1 and 2.

118 Allehone M Abebe, 'Of Shaming and Bargaining: African States and the Universal Periodic Review of the United Nations Human Rights Council' (2009) Human Rights Law Review 1, 19-21; Dominguez Redondo, 'The Universal Periodic Review of the UN Human Rights Council: An Assessment of the First Session' (2008) 7(3) Chinese Journal of International Law 731; Edward McMahon, (note 33 above) 19-25.
} 
I, Nigeria accepted a general recommendation ( $\mathrm{R} 4$ ) touching on the death penalty from Benin, ${ }^{119}$ but rejected similar general recommendations from Western states such as the UK and Sweden. ${ }^{120}$ Also, during UPR II, Chad accepted a recommendation from Cape Verde (on violence against women, female genital mutilation and forced marriages), but rejected a similar recommendation from Italy, even though both recommendations addressed the same issues and fell in the same action category. ${ }^{121}$ This provides evidence of the positive outcome of identification as a micro process of acculturation by causing recommendations made by states within a regional block, which otherwise may not have been accepted, to be accepted by members of that regional block. However, the extent to which the UPR could transform the culture on gay rights within African states through acculturation remains to be seen, but the cognitive pressures associated with acculturation are an important part of the process.

Cognitive pressures associated with the acculturation micro process of identification can push the language of human rights into some moral commitments within particular cultures even in terms that challenge one or more aspects of that culture. Benjamin Gregg employed a cognitive approach rather than a normative one to show how human rights norms can be advanced as rights internal to any given community's culture by means of cognitive re-framing. ${ }^{122} \mathrm{He}$ argued that "an idea once external can become internal through system-level learning."123 While examining the issue of female genital mutilation in Africa, he noted that a cognitive rule can be deployed that revises local normative rules that justify female genital mutilation, but that such a cognitive rule has to be "indigenized." ${ }^{24}$ For example reframing female genital mutilation as a technical, medical issue rather than a normative human rights concern can

\footnotetext{
${ }^{119}$ HRC UPR I Report - Nigeria (note 27 above), para 14.

${ }^{120}$ Ibid. Another example of the positive impact of regionalism in the UPR, with regard to Africa states, was evident in the review of Chad. During Chad's UPR II, Togo and Czech Republic recommended that Chad 'Ratify the Optional Convention against Torture and Other Cruel, inhuman or Degrading Treatment or Punishment.' Even though both recommendations were of the same action category of specific recommendations (R5), Chad refused to accept the same recommendation from Czech Republic because it added 'without delay'. See UN Human Rights Council, Report of the Working Group on the Universal Periodic Review - Chad, UN Doc A/HRC/25/14 (3 January 2014) para 110.18 and 110.120.

${ }^{121}$ UN Human Rights Council, 'Report of the Working Group on the Universal Periodic Review - Chad: Addendum' UN Doc A/HRC/25/14/Add 1 (3 January 2014) 2. See ibid paras 110.107 and 110.110, read together with Report of the HRC on its $25^{\text {th }}$ Session, UN Doc A/HRC/25/2, paras 110.107 and 110.110.

122 Benjamin Gregg, 'Deploying Cognitive Sociology to Advance Human Rights' (2010) 9 Comparative Sociology 279, 289

123 Ibid.

124 Ibid 304.
} 
advance the human rights issue as internal to the African culture. ${ }^{125}$ Such an approach can be equally beneficial to other cultural aspects affecting the engagement of Nigeria with the UPR.

As the acculturation process progresses, it will be difficult for a state to sustain purely rhetorical commitments because of external "audience" effects. External audience effects are generated by national and transnational human rights advocacy networks when they engage governments in a dialogue about norm implementation and hold them accountable for their human rights rhetoric. The publicity of a government's UPR commitments creates expectations among informed citizens and NGOs/CSOs, making it difficult for the government to contradict or deviate from the accepted commitment/recommendations. Dia in his study ${ }^{126}$ noted how the Communist regimes' commitments under the Helsinki Accords were frequently referenced in popular struggles for freedom of association and freedom of expression. ${ }^{127}$ Citizens over time may pressure their government to live up to their human rights rhetoric and commitments. This is referred to by O'Brien and $\mathrm{Li}$ as "rightful resistance". ${ }^{128}$ They suggest that this grows from the space created when the state's international commitment is disconnected from local practice. ${ }^{129}$ According to O'Brien and Li, "so long as a gap exists between rights promised and rights delivered, there is always room for rightful resistance to emerge." ${ }^{130}$ In the case of Nigeria, there is a space for civil society to hold the government accountable for its UPR commitments. A strategic and well-coordinated campaign by NGOs can contribute to meaningful human rights improvement within a state.

Continuous engagement of Nigeria with the UPR process has the potential to over time narrow the implementation gap. As earlier indicated, some of the UPR I recommendations to Nigeria that were not implemented during the specified time were subsequently implemented. The adoption of a UPR implementation action plan would accelerate and provide greater certainty on the implementation process. In addition, continuous engagement with the UPR process may over time influence states even on issues which it rejected in its previous review. As

\footnotetext{
${ }^{125}$ Human Rights Norms against Child Prostitution in Asia were advanced internally by means of cognitive reframing. See ibid 289.

${ }^{126}$ Xinyuan Dai, International Institutions and National Policies (Cambridge University Press, 2007).

127 Ibid 120.

${ }^{128}$ Kevin J O'Brien and Li Lianjiang, Rightful Resistance in Rural China (Cambridge University Press, 2006) 1524; Note however that the number of offences subject to the death penalty is still very high in China.

${ }^{129}$ Relating to the situation where public conformity is disconnected from local practice see Kevin J O'Brien and Li Lianjiang, Rightful Resistance in Rural China (Cambridge University Press, 2006) 64.

${ }^{130}$ Ibid.
} 
governments within nations change, so do their views on human rights issues so as to identify with the wider community with which they interact. This was the case with Côte d'Ivoire. During UPR I, the government of President Laurent Gbagbo rejected recommendations from the UK, Brazil and Czech Republic to sign and ratify OP-CAT. ${ }^{131}$ During UPR II, the government of President Alassane Ouattara accepted the same recommendations from states such as Ghana, Tunisia, Czech Republic, Uruguay and Burkina Faso. ${ }^{132}$ With the new Nigerian government that was elected in 2015, it remains to be determined whether specific recommendations on the death penalty and the rights of sexual minorities may subsequently receive a positive response from the new government during UPR III. Acculturation in this context is seen as a continuous process which may over time produce a positive outcome. ${ }^{133}$

\section{THE SPIRAL EFFECT OF THE FIGHT AGAINST BOKO HARAM ON NIGERIA'S UPR ENGAGEMENT}

Just as terrorism has a grave impact on human rights, so too anti-terrorism laws and policies can have serious implications for human rights and individual freedoms. ${ }^{134}$ When conflicts within or between states pose a threat to the nation or citizens, governments easily justify repressive measures and human rights considerations may thereby be weakened. The role of conflict and security threats in Nigeria in hindering norm compliance is an important aspect to consider when examining its engagement with the UPR. There is always a tendency for governments to trade off human rights considerations in the name of counter-terrorism measures or national security. Human rights violations mostly committed by governments under the pretext of counter terrorism measures include torture, extra-judicial executions and secret and arbitrary detention. During UPR I, Nigeria accepted a recommendation to take "all practical measures" to end "extrajudicial executions" and "step up its measures to halt torture." 135 This section considers whether the escalation of the conflict between the

\footnotetext{
${ }^{131}$ UN Human Rights Council, Report of the Working Group on the Universal Periodic Review - Cote d'Ivoire, $13^{\text {th }}$ sess, UN Doc A/HRC/13/9 (4 January 2010) paras 101.7-101.9.

${ }^{132}$ UN Human Rights Council, Report of the Working Group on the Universal Periodic Review - Cote d'Ivoire, $27^{\text {th }}$ sess, UN Doc A/HRC/27/6 (7 July 2014) paras 127.3-127.4 and 127.5 respectively.

${ }^{133}$ For a description of process and outcome-based conceptions of acculturation See John W Berry, 'Conceptual Approaches to Acculturation' in Kevin M Chung, Pamela Ball Organista and Gerardo Marin (eds), Acculturation: Advances in Theory, Measurement and Applied Research (American Psychology Association, 2003).

${ }^{134}$ Cephas Lumina, 'Counter Terrorism Legislation and the Protection of Human Rights: A Survey of Selected International Practice' (2007) 7(1) African Human Rights Journal 36.

${ }^{135}$ HRC UPR I Report - Nigeria (note 27 above), para 22.
} 
government and Boko Haram terrorist group after UPR I had a regressive effect on Nigeria's subsequent engagement with the UPR.

There is some obscurity surrounding the origin of Boko Haram. Attempts at explaining the origin and leadership of the group have generated some confusion. ${ }^{136}$ Boko Haram, literally translated to mean "western education/civilization is sin," is a sect whose early recruits were indoctrinated "to believe that their state of hopelessness was caused by government which imposed Western education on them and failed to manage the resources of the country to their benefits." 137

While the existence of the sect has been traced as far back as $1995,{ }^{138}$ it was only after Nigeria's UPR I in 2009 that the conflict between the sect and the government escalated. Two particular incidents escalated the conflict between the government and Boko Haram terrorist group. These were the bombing of the Nigerian Police Headquarters in Abuja on 16 June 2011 and the bombing of the United Nations House in Abuja on 26 August 2011. Prior to these incidents, Boko Haram was apparently not understood as a threat to peace and to the protection of human rights in Nigeria and the region. None of the 32 recommendations during Nigeria's UPR I session on 9 February 2009 addressed the issue of terrorism. It only became a major concern during UPR II on 27 October 2013, receiving three recommendations from France, Portugal and the Republic of Korea. ${ }^{139}$

A major counter terrorism response by the Nigerian government immediately followed the two major incidents above. The government enacted the Terrorism (Prevention) Act 2011 (hereafter 'TPA'). ${ }^{140}$ This was amended on February 21, 2013 by the Terrorism (Prevention) (Amendment) Act 2013 (hereafter 'TPA' as Amended). While most of its provisions are human rights compliant, some are not. Some counter terrorism measures have been found to have

\footnotetext{
${ }^{136}$ See Simeon H O Alozieuwa, 'Contending Theories on Nigeria's Security Challenge in the Era of Boko Haram Insurgency’ (2012) 7(1) Peace and Conflict Review 1.

${ }^{137}$ N C Okereke, 'Implementing the Nigerian Defence Policy: Reflections on the Boko Haram Crisis' in O Mbachu and A A Sokoto (eds), Nigerian Defence and Security: Policies and Strategies (Medusa Academic Publishers Ltd, 2011) 450; for the socio-economic, political fued, vengeance, Islamic state and conspiracy theories explaining the development of Boko Haram sect see Simeon H O Alozieuwa, 'Contending Theories on Nigeria's Security Challenge in the Era of Boko Haram Insurgency’ (2012) 7(1) Peace and Conflict Review 1.

138 Jideofo Adibe, 'Boko Haram: One Sect, Conflicting Narratives' (2012) 9(1) African Renaissance 50.

${ }^{139}$ HRC UPR II Report-Nigeria (note 41 above) paras 135.170, 135.171 and 137.171.

${ }^{140}$ The 41 sections of the TPA define and proscribe acts of terrorism including methods of intelligence gathering, prevention, investigation and prosecution of alleged terrorists and also mutual legal assistance.
} 
grave impact on the enjoyment of human rights. ${ }^{141}$ For example section 32(1) of TPA (as Amended) which provides that the Federal High Court "shall have the sole jurisdiction to try an offence and impose the penalties specified in this Act"142 is in conflict with the Child Rights Act $2003,{ }^{143}$ pursuant to which a child is to be tried by a Family Court. ${ }^{144}$ This also goes against the UPR recommendations Nigeria accepted from Poland and Slovakia to "[e]nsure that neither the death penalty nor life sentence is imposed for offences committed by persons below 18 years of age". ${ }^{145}$

Furthermore, subjecting the proscribed acts or omissions in the TPA ${ }^{146}$ (including "threats") "to maximum of death penalty", ${ }^{147}$ irrespective of the gravity of the offence, is open to abuse and undermines the principle of proportionality. Amnesty International notes this fact and other inconsistencies with the TPA to which it stated:

Key provisions of the Act are incompatible with Nigeria's human rights obligations. Many of the provisions of the Act use terms and definitions that are imprecise and overbroad in scope, violating the 'legality' requirement for criminal offences, and/or unlawfully restricting a range of rights - such as freedom of thought, conscience and religion, freedom of opinion and expression, freedom of association and freedom of assembly - by failing to adhere to the requirements of demonstrable proportionality... some provisions relating to investigation, detention, and trial are not consistent with various provisions of human rights law. ${ }^{148}$

Another prominent issue during Nigeria's UPR related to the government's anti-terrorism campaign was torture and extra-judicial executions. Six states including Benin, Germany and Portugal recommended during UPR I that Nigeria investigate and put an end to the use of

\footnotetext{
${ }^{141}$ See Edward Mogirea and Kennedy Mkutu Agade, 'Counter-terrorism in Kenya' (2011) 29(4) Journal of Contemporary African Studies 473; Arthur Chaskalson, 'The Widening Gyre: Counter-Terrorism, Human Rights And The Rule Of Law' (2008) The Cambridge Law Journal, 67, 69-91; Alex Conte, 'Human Rights Compliance in the Fight Against Terrorism' in Alex Conte, Human Rights in the Prevention and Punishment of Terrorism (Springer, 2010) 389.

${ }^{142}$ Terrorism (Prevention) Act 2011 (Nigeria), s 32 (1).

${ }^{143}$ This is the law domesticated the Convention on the Rights of the Child.

${ }^{144}$ Defined as a person below 18 years.

${ }^{145}$ HRC UPR II Report-Nigeria (note 41 above) paras 137.28 and 137.29.

146 Terrorism (Prevention) (Amendment) Act, 2013 s 1(2).

147 Terrorism (Prevention) (Amendment) Act, 2013 s 2.

148 Amnesty International, 'Nigeria: Trapped in the Cycle of Violence' (2012) $47<$ https://www.amnesty.org/download/Documents/16000/afr440432012en.pdf >.
} 
torture and extra-judicial executions by the police. ${ }^{149}$ These recommendations were accepted by the Nigerian government.

Despite the above UPR commitment to end extra-judicial executions, there has been an increase in extra-judicial executions. Government security forces have been implicated in numerous extra-judicial killings, torture, and other serious human rights abuses. ${ }^{150}$ The escalation of violence between Boko Haram and the government was prompted by an act of extra-judicial execution. ${ }^{151}$ It was the death of Yussuf, a Boko Haram leader in police custody that triggered Boko Haram to perpetuate the two major bombings in 2011 as acts of retaliation. ${ }^{152}$ During UPR II on Nigeria, HRAN reported an increase in the number of extrajudicial executions, torture and ill treatment committed by the Joint Task Force set up by the government in the name of fighting terrorism. ${ }^{153}$

Amnesty International also reported an increase in the number of extra-judicial executions by the government. It reported that over 950 people died in detention facilities ran by the Joint Task Force within the first six months of 2013. ${ }^{154}$ Similarly, just one month after Nigeria's UPR I, Human Rights Watch documented 28 alleged extra-judicial executions committed by the government police between 28 July and 1 August $2009^{155}$ and 27 extra-judicial executions carried out by the military in Maiduguri between July 2009 and May 2012. ${ }^{156}$ The Nigerian National Human Rights Commission in its UPR II submission noted that there is no body set up to monitor and investigate extra-judicial executions in Nigeria and that the National Committee against Torture has no investigative powers. ${ }^{157}$ During UPR II, Portugal recommended that the Nigerian government should tackle the problem of extra-judicial

\footnotetext{
${ }^{149}$ Ibid paras 14, 22 and 23.

${ }^{150}$ See Human Rights Watch, 'Spiralling Violence: Boko Haram Attacks and Security Force Abuses in Nigeria' (October 2012) Human Rights Watch 61; Human Rights Agenda Network (HRAN), above n 53.

${ }^{151}$ Simeon H O Alozieuwa, 'Contending Theories on Nigeria's Security Challenge in the Era of Boko Haram Insurgency’ (2012) 7(1) Peace and Conflict Review 1, 2.

152 Ibid.

${ }^{153}$ See Human Rights Agenda Network (HRAN), above n 53, 4.

154 Amnesty International, 'Nigeria: Authorities Must Investigate Deaths of Boko Haram Suspects in Military Custody', Index No. AFR 44/025/2013 (16 October 2013).

${ }^{155}$ Human Rights Watch, 'Spiralling Violence: Boko Haram Attacks and Security Force Abuses in Nigeria' above n 150.

${ }^{156}$ Ibid 64.

${ }^{157}$ National Human Rights Commission of Nigeria, 'National Human Rights Commission Table of Commentary on 2009 UPR recommendations and the extent of Compliance' para $22<$ https://uprdoc.ohchr.org/uprweb/downloadfile.aspx?filename=556\&file=Annexe1 $>$.
} 
executions by mainstreaming human rights into counter terrorism laws and policies. ${ }^{158}$ This can contribute to draw a clear line between law enforcement and terrorism. Besides, torture and extra-judicial executions are non-derogable rights recognised by international human rights law and Nigeria (as of February 2017) did not officially derogate from the ICCPR in its counter terrorism campaign. ${ }^{159}$ Nigeria accepted all five recommendations during UPR II to end, prevent and investigate extra-judicial executions and torture by security forces, and to guarantee respect for human rights in its fight against terrorism. ${ }^{160}$ The extent to which this is implemented can only be determined by the end of UPR II implementation timeframe in 2018.

Acculturation falls within the broader socialisation theory on the ways in which human rights norms become socialised into domestic settings of states. Prominent among these theories is the five-stage spiral model developed by Risse, Ropp and Sikkink. A major deficiency in the various theories of human rights norm socialisation is their failure to consider the regressive effect of serious conflicts and security threats on human rights norm implementation. This section with focus on Boko Haram terrorism has demonstrated that conflicts and security threats can have a regressive effect on state human rights compliance. The fight against Boko Haram terrorism in Nigeria has contributed to an increase by government police and militia in the perpetuation of torture and extra-judicial executions, despite its UPR commitments and other human rights obligations.

\section{CONCLUSION}

This article, with a focus Nigeria, underscores the potential for human rights mechanisms based on cooperation and dialogue to help cause human rights changes within states in a subtle but significant way. Exclusive reliance on coercive/confrontational mechanisms could undermine the potential for cooperative mechanisms to contribute to human rights changes within states. Elvira Domínguez Redondo earlier expressed this point when he states:

\footnotetext{
${ }^{158}$ HRC UPR II Report-Nigeria (note 41 above) para 135.171.

${ }^{159}$ International Covenant on Civil and Political Rights, opened for signature 16 December 1966, 999 UNTS 14668 (entered into force 23 March 1976) arts 6 and 7. Extra-judicial execution as a non-derogable right is derived from the right to life.

${ }^{160}$ HRC UPR II Report-Nigeria (note 41 above), paras 135.68-135.70 and 135.170.
} 
[T]hose in charge of human rights mechanisms, scholars and practitioners tend to neglect the potential value of cooperative approaches to human rights implementation and focus instead on the confrontational approaches ${ }^{161}$

The UPR provides a platform for acculturation that promotes cooperation and encourages continuous improvement of the human rights situation within states. Applying the theory of acculturation contributes to an understanding of the efficacy of human rights strategies based on cooperation. As a cooperative mechanism, the UPR can be beneficial in realising incremental progress in human rights, as opposed to immediate, especially towards the decriminalisation of same-sex relations which is a culturally sensitive issue within Nigeria and many other African states.

Nigeria's acceptance of most of the UPR I and II recommendations (about 90\% and 84\% respectively), indicate its receptiveness to peer recommendations. However, an important aspect limiting the extent of this receptiveness was cultural relativism. Cultural relativism limited Nigeria's active engagement as it was not willing to accept recommendations on sexual orientation which it considered hyper-sensitive in socio-cultural terms. Regionalism on the other hand attracted a stronger engagement from Nigeria evidenced by its acceptance of all UPR I recommendations from African states and rejecting only about $1 \%$ of their recommendations during UPR II. Some may perceive regionalism to be detrimental to the UPR mechanism. This is true to the extent that it may prevent cooperation across the regional group and affect the universality of the UPR process. However, this may not entirely be the case because it facilitates acculturation by causing recommendations made by the regional block, which otherwise may not have been accepted, to be accepted by members of that regional block.

Nigeria's implementation of UPR recommendations provided further insights into the potential value of the UPR process by the extent to which it contributed to improve the human rights situation on the ground. About $45 \%$ of the recommendations which were either fully or partially implemented by Nigeria indicated an important contribution of the UPR in improving the human rights situation on the ground. However, there is a significant compliance gap which poses a major challenge as was addressed on issues such as justice and detention, women's

${ }^{161}$ Redondo (note 93 above) 683. 
rights and torture. But as was argued, acculturation can narrow this gap over time through the internal and external audience effects generated by effective NGO engagement. This was seen in instances where certain steps where taking by the state to implement UPR recommendations beyond the implementation timeframe.

In particular, issues that are hyper-sensitive in African cultural terms such as the recommendations on sexual orientation can be addressed by internal cognitive pressures through Greggs cognitive re-framing approach. Approaches that employ coercion or recommend immediate normative solutions may experience negative resistance which may cause further regression. For example, calls for immediate decriminalisation or threats, such as David Cameron's threat to withhold UK aid from governments that do not reform legislation banning homosexuality, ${ }^{162}$ was met with specific legislation further criminalising same sex unions in some countries like Nigeria and Uganda. ${ }^{163}$ This further indicates the limits and dangers of coercive or confrontational approaches in addressing human rights issues which are perceived to be hyper-sensitive in socio-cultural terms.

Equally important from the analysis in this article was that conflicts and security threats such as terrorism can have a regression effect on a state's human rights compliance. Despite Nigeria's UPR commitment with respect to putting a moratorium on the death penalty and ending torture and extrajudicial execution, the escalation of the conflict between Boko Haram and the government resulted in further human rights violation. It is therefore important for the state to mainstream human rights standards in its counter terrorism approach. Notwithstanding, the UPR mechanism has the potential to address major human rights concerns in an inclusive and cooperative manner that can lead to incremental improvement of the human rights situation on the ground. While there is the potential for acculturation by way of identification and cognitive pressures from peers, terrorism and political instability may present a risk of regression but the potential value of the UPR process in addressing human rights concerns with states should not be undermined.

\footnotetext{
${ }^{162}$ BBC News, 'Cameron threat to dock some UK aid to anti-gay nations' (2011) http://www.bbc.com/news/uk15511081.

${ }^{163}$ Same Sex Marriage Prohibition Act 2013 (Nigeria); Uganda Anti-Homosexuality Act, 2014 (Uganda).
} 